\title{
Perbedaan Pendekatan Pembelajaran Berbasis Masalah Berbantuan Software Dengan Pendekatan Open Ended Berbantuan Software Terhadap Kemampuan Pemecahan Masalah Matematis
}

\author{
Adi Suarman Situmorang 1 \\ ${ }^{1}$ Pendidikan Matematika FKIP Univ. HKBP Nommensen \\ adisuarmansitumorang@uhn.ac.id
}

\begin{abstract}
Abstrak
Tujuan penelitian ini adalah untuk melihat perbedaan peningkatan pemecahan masalah matematika siswa yang diajarkan dengan Pendekatan Pembelajaran Berbasis Masalah berbantuan Software dan Pendekatan Open Ended berbantuan Software. Jenis penelitian yang digunakan adalah penelitian quasi eksperimen, dengan populasi dalam penelitian ini adalah seluruh siswa kelas X SMA Swasta Parulian 1 Medan yang terdiri dari 6 kelas. Hasil penelitian menunjukkan bahwa rata-rata nilai pada kelas eksperimen I yaitu 74,76 sedangkan rata-rata pada kelas eksperimen II yaitu 67,23. Hasil uji prasyarat data proses menyatakan sampel terdistribusi normal dan homogen. Selanjutnya dilakukan uji t satu pihak $(\alpha=0.05)$. Dari hasil uji t satu pihak dapat disimpulkan bahwa pemecahan masalah matematika siswa yang diajarkan dengan Pembelajaran Berbasis Masalah berbantuan Software lebih baik daripada pemecahan masalah matematika siswa yang diajarkan dengan Pendekatan Open Ended berbantuan Software di kelas X SMA Swasta Parulian 1 Medan.
\end{abstract}

Kata Kunci: Pendekatan Berbasis Masalah, Open Ended, Pemecahan Masalah Matematis

\section{Pendahuluan}

Kemajuan suatu bangsa ditentukan dari bagaimana perkembangan pendidikan bagi anak-anak bangsa itu. Kemajuan dalam satuan waktu jangka panjang akan dapat memprediksi kualitas bangsa pada sekian puluh tahun ke depan. Akhir dari hasil pendidikan yang terencana menghasilkan buah di mana masyarakat rata-rata berpendidikan tinggi. Sehingga pendidikan merupakan faktor yang paling besar peranannya dalam kelangsungan hidup manusia dan perkembangan suatu bangsa. Begitu juga dengan perkembangan ilmu pengetahuan dan teknologi (IPTEK) saat ini sangat pesat sehingga informasi yang terjadi di belahan dunia mana pun bisa dapat kita ketahui segera, waktu dan batas negara sudah tidak menjadi penghalang lagi. Seiring perkembangan IPTEK tersebut, pemecahan masalah, berfikir kritis, kreatif dan kemampuan komunikasi diduga dapat dikembangkan melalui pembelajaran matematika (Situmorang Adi S., 2018).

Matematika adalah kunci ke arah peluang-peluang. Bagi seorang siswa keberhasilan mempelajari matematika akan membuka pintu karir yang cemerlang. Bagi pemimpin negaranegara matematika juga sangat diperlukan dalam pengambilan keputusan dan kebijakan yang tepat dalam negaranya masing-masing. Bagi suatu negara, matematika akan menyiapkan warganya untuk bersaing dan berkompetisi di bidang ekonomi dan teknologi (Pangaribuan Lena, 2017). 
Sebagai antisipasi dalam menghadapi permasalahan era globalisasi tersebut, dunia pendidikan dituntut untuk mempersiapkan sumber daya manusia yang bermutu, berwawasan, dan memiliki keunggulan yang kompetitif (Siahaan Friska, 2017). Sebagaimana yang tercantum dalam Undang-undang pendidikan No 20 Tahun 2003 menjelaskan bahwa pendidikan adalah usaha sadar dan terencana untuk mewujudkan suasana belajar dan proses pembelajaran agar peserta didik secara aktif, mengembangkan potensi dirinya untuk memiliki spiritual keagamaan, pengendalian diri, kepribadian, kecerdasan, akhlak mulia, serta keterampilan yang diperlukan dirinya, masyarakat, bangsa, dan negara (Sitorus Parlindungan, 2016).

Pemerintah juga menekankan melalui Permendiknas nomor 22 tahun 2001 tentang standar isi Satuan Pendidikan Dasar dan Menengah (Depdiknas, 2006) bahwa matematika mendasari perkembangan kemajuan teknologi, mempunyai peran penting dalam berbagai disiplin, dan memajukan daya pikir manusia, matematika diberikan sejak dini disekolah untuk membekali anak dengan kemampuan berpikir logis, analitis, sistematis, kritis, kreatif, serta kemampuan berkerja sama. Semua kemampuan itu merupakan bekal dan modal penting yang diperlukan anak dalam meniti kehidupan di masa yang akan datang dengan penuh tantangan dan perubahan yang cepat. Matematika sangat penting perannya setiap jenjang pendidikan. Matematika sebagai The Queen of sciences mempunyai peran yang sangat penting dalam ilmu pengetahuan dan teknologi (Gultom Sanggam, 2018).

Oleh karena itu matematika sebagai mata pelajaran perlu diberikan kepada semua peserta didik mulai dari sekolah dasar untuk membekali mereka dengan kemampuan berpikir logis, analitis, sistematis, kritis dan kreatif serta berkemampuan bekerja sama. Karena dengan belajar matematika, peserta didik akan belajar bernalar secara kritis, kreatif dan aktif. Tetapi pada kenyataannya permasalahan yang sering menjadi perdebatan dikalangan para orang tua siswa, guru dan pakar pendidikan pada saat ini adalah Kemampuan pemecahan masalah siswa masih rendah yang menyebabkan hasil belajar matematika siswa masih jauh dari kata memuaskan. Keberhasilan pembelajaran matematika ditentukan oleh seberapa baik hasil belajar yang dicapai siswa setelah mengikuti pelajaran.

Dari beberapa hasil pengamatan yang dilakukan oleh beberapa ahli pendidikan di Indonesia menyimpulkan bahwa faktor penyebab rendahnya hasil belajar matematika siswa adalah faktor ekstern (yang berasal dari luar diri siswa) dan faktor intern (yang berasal dari dalam diri siswa). Dilihat dari segi faktor ekstern yaitu diduga kemampuan guru kurang dapat memilih metode yang cocok didalam penyampaian pelajaran matematika yang menyebabkan proses belajar mengajar berlangsung kurang efektif sedangkan faktor intern yaitu kurangnya pemahaman siswa terhadap materi yang diajarkan serta perhatian dan minat yang timbul dari diri anak tersebut sehingga siswa tidak mampu untuk menyelesaikan masalah matematika yang disajikan oleh Guru. Seperti yang diungkapkan oleh Suherman bahwa dalam pelaksanaan pembelajaran matematika sekarang ini pada umumnya guru masih menggunakan metode konvensional yaitu guru masih mendominasi kelas, siswa pasif (datang, duduk, nonton, berlatih dan lupa) (Siagian Beslina, 2017). Guru memberitahukan konsep, siswa menerima bahan jadi. Demikian juga dalam latihan, dari tahun ke tahun soal yang diberikan adalah soal-soal yang itu-itu juga dan tidak bervariasi. Untuk mengikuti pembelajaran di sekolah, kebanyakan siswa tidak siap terlebih dahulu dengan membaca bahan yang akan dipelajari, siswa datang tanpa bekal pengetahuan seperti membawa wadah kosong (Sianipar Linda, 2017).

Pembelajaran seperti ini adalah pembelajaran yang hanya berpusat pada guru. Siswa hanya mendengar, memperhatikan, dan menghafal bagaimana guru menyelesaikan soal-soal. Siswa tidak diberikan kesempatan untuk memberikan pendapat sendiri bagaimana cara menyelesaikan soal-soal tersebut. Seyogianya, dalam pembelajaran khususnya dalam pembelajaran matematika siswa yang seharusnya berperan aktif sebagai seorang pebelajar. 
Berdasarkan hal tersebut, maka saya menyimpulkan bahwa perlu diadakannya suatu gebrakan untuk meningkatkan hasil belajar matematika, pola berfikir siswa dan khususnya kemampuan pemecahan masalah matematis siswa di Indonesia agar siswa kita dapat bersaing dengan siswasiswi dari negara lain dan yang terpenting lagi bahwa kemampuan tersebut harus ditanamkan dalam diri setiap siswa untuk menjadi bekal hidupnya kelak. Oleh karena itu, perubahan paradigma mengajarkan matematika di setiap kelas di setiap tingkatan sekolah harus selalu di suarakan. Perubahan tersebut secara sederhana dimulai dari sebaiknya guru mengurangi dominasinya di kelas dengan menerapkan pembelajaran matematika yang dapat melatih siswa untuk menemukan dan membangun sendiri pengetahuannya. Dengan memberi kesempatan yang lebih luas pada siswa untuk berinteraksi dengan teman belajarnya, maka dengan sendirinya akan melatih siswa meningkatkan kemampuan pemahaman, komunikasi, koneksi, penalaran, dan pemecahan masalah.

Salah satu model pembelajaran yang diprediksikan mampu meningkatkan kemampuan pemecahan masalah matematika siswa adalah model Pembelajaran Berbasis Masalah (PBM) yang merupakan model yang efektif untuk pembelajaran proses berpikir tingkat tinggi (Jamil Suprihatiningrum, 2012: 216). Mempunyai kemampuan berfikir tingkat tinggi artinya siswa sudah memiliki kecakapan berfikir yang cukup untuk memecahkan masalah-masalah matematis yang ada di dalam pembelajaran matematika maupun di dalam kehidupannya sehari hari. Ditambah dengan penggunaan media pembelajaran matematika tersebut yang menarik diramalkan akan semakin menarik minat siswa dalam pembelajaran matematika dan memudahkan guru untuk mengarahkan siswa untuk mencapai indikator kemampuan yang diharapkan oleh guru itu sendiri.

Pada model pembelajaran berbasis masalah (PBM) ini, siswa dihadapkan pada situasi atau masalah yang dapat mengantarnya untuk lebih mengenal objek matematika, melibatkan siswa melakukan proses doing math secara aktif, mengemukakan kembali ide matematika dalam membentuk pemahaman baru. Oleh karena itu, kecenderungan untuk meningkatnya kemampuan pemecahan masalah matematis menjadi lebih terbuka. Hal senada diutarakan oleh Arends (2008) bahwa salah satu model pembelajaran konstruktivis yang mengaktifkan siswa dalam berkolaborasi untuk memecahkan masalah adalah model pembelajaran berbasis masalah. Pembelajaran berbasis masalah ini menurut Arends (2008) memiliki esensi yaitu menyajikan berbagai kondisi pemasalahan yang real, yang nantinya akan dipecahkan oleh siswa melalui berbagai penyelidikan dan investigasi.

Selain pendekatan PBM pendekatan pembalajaran yang dapat digunakan dalam upaya mengembangkan dan meningkatkan kemampuan pemecahan masalah adalah pendekatan OPEN ENDED. Menurut Nohda sebagaimana dikutip oleh Suherman (2003), tujuan dari pendekatan Open Ended adalah membantu mengembangkan kegiatan kreatif dan pola pikir matematika siswa melalui problem solving secara simultan. Suherman (2003) juga mengungkapkan bahwa pendekatan open-ended menjanjikan suatu kesempatan kepada siswa untuk menginvestigasi berbagai strategi dan cara menyelesaikan masalah yang dapat mengembangkan kemampuan berpikir matematika siswa dan pada saat yang sama kegiatan kreatif dari setiap siswa dapat terkomunikasikan dalam proses belajar mengajar.

Untuk menunjang pembelajaran yang mengaktifkan siswa dan membiasakan siswa menghadapi dan mengatasi masalah-masalah matematis adalah dengan memanfaatkan media pembelajaran berupa alat peraga dalam pembelajaran matematika disekolah. Karena menurut Suprihatiningrum (2013: 317) "Tidak semua yang dipelajari siswa adalah hal-hal yang konkret. Banyak pula konsep-konsep abstrak yang menuntut pemahaman siswa dalam mempelajarinya. Untuk mempermudah siswa dalam mempelajari hal-hal abstrak dapat digunakan media."

Media belajar matematika terbagi atas dua jenis menurut sifatnya, yaitu visual dan virtual, kemudian bahan dan alat yang dikenal dengan software dan hardware itulah yang secara sempit 
dinamakan media pembelajaran . Salah satu media yang dapat digunakan dalam pembelajaran matematika adalah media berbasis computer dengan software yang digunakan adalah Cabri 3D, karena software ini dapat mempersembahkan pembelajaran yang dinamik, berorientasi pada eksperimental, observasi, eksplorasi, yang konjuktur dan karakteristik dari software ini sangat mempunyai peranan yang penting dalam membantu siswa untuk meningkatkan kemampuan pemecahan masalah dan pemahaman konsep siswa akan materi geometri khususnya pada ruang dimensi 3.

Software Cabri 3D adalah salah satu software atau perangkat lunak yang sangat membantu siswa dalam proses belajar. Pemanfaatan Software Cabri 3D dalam pembelajaran dikelas merupakan suatu inovasi baru dalam pembelajaran matematika, karena yang selama ini kita ketahui bahwa dalam pembelajaran lebih didominasi oleh guru, akan tetapi dengan mengguanakan Software Cabri 3D siswa dapat mengembangkan cara belajarnya dengan lebih baik. Penggunanan Software Cabri 3D selain dapat mengakomodasi siswa yang lamban juga dapat memudahkan guru dalam menyampaikan materi pelajaran, memudahkan siswa untuk menyerap apa yang disampaikan oleh guru. Selain membangkitkan motivasi dan minat belajar siswa, media pembelajaran juga dapat meningkatkan kemampuan pemecahan masalah matematis siswa.

Berdasarkan permasalahan diatas, peneliti mencoba mengkolaborasikan pendekatan Pembelajaran Berbasis Masalah berbantuan media komputer (Software Cabri 3D) dan Pendekatan Pembelajaran Open Ended dengan berbantuan media komputer (Software Cabri 3D) yang bertujuan untuk meningkatkan kemampuan pemecahan masalah siswa terhadap matematika. Software Cabri 3D dalam kolaborasi ini, diharapkan bisa menghadirkan bentuk gambar atau animasi yang lebih menarik dan berkesan, sehingga pembelajaran yang dialami siswa lebih menyenangkan dan tidak membosankan. Berdasarkan uraian-uraian di atas, maka dapat diuraikan satu hal yang perlu diungkap secara mendalam terkait dengan pembelajaran matematika berdasarkan pendekatan pembelajaran berbasis masalah dan pendekatan Open Ended yaitu apakah pembelajaran berbasis masalah berbantuan software Cabri 3D dan pendekatan Open Ended yang juga berbantuan software Cabri 3D dapat meningkatkan kemampuan pemecahan masalah matematis siswa pada jenjang sekolah menengah keatas?

\section{Metode Penelitian}

Penelitian ini dilakukan di SMA Swasta Parulian 1 Medan yang pelaksanaannya berlangsung pada semester genap tahun ajaran 2016/2017, yaitu pada bulan April selama 3 kali pertemuan (6 jam pelajaran $=6 \times 40$ menit) untuk masing-masing kelas sampel. Pelaksanaan perlakuan dalam bentuk kegiatan pembelajaran disesuaikan dengan kalender pendidikan. Populasi penelitian ini adalah seluruh siswa kelas X SMA Swasta Parulian 1 Medan yang terdiri dari 4 kelas paralel. Pemilihan siswa kelas X sebagai populasi dalam penelitian ini didasarkan pada pertimbangan tingkat perkembangan kognitif siswa pada masa ini ada pada tahap operasional konkrit, sehingga sesuai dengan pembelajaran berbasis masalah. Selain itu, siswa kelas $\mathrm{X}$ telah mendapat materi prasyarat di SMP mengenai pokok bahasan yang akan diteliti, yaitu menentukan Jarak dalam Ruang.

Sampel penelitian dipilih secara acak (cluster random sampling) untuk ditetapkan menjadi kelompok eksperimen I dan eksperimen II. Tahap pemilihan secara acak dimungkinkan karena berdasarkan informasi dari kepala sekolah dan guru pendistribusian siswa pada tiap kelas merata secara heterogen. Hal ini sesuai dengan pendapat Russefendi (1998: 78) salah satu cara memilih sampel mewakili populasinya adalah cara random sederhana, yaitu bila setiap anggota dari populasi mempunyai kesempatan yang sama untuk dipilih. Kelompok pendekatan pembelajaran berbasis masalah dan kelompok pembelajaran open ended dibagi menjadi kelompok-kelompok kecil sebanyak tiga atau empat orang. Anggota kelompoknya heterogen terdiri dari siswa 
pandai, sedang dan lemah. Teknik penentuan kelompok berdasarkan hasil ulangan harian matematika.

Sebagai upaya untuk mendapatkan data dan informasi yang lengkap mengenai hal-hal yang ingin dikaji melalui penelitian, maka dalam penelitian ini ada 2 alat pengumpulan data, yaitu: 1) Observasi. Observasi merupakan salah satu cara pengumpulan data yang dilakukan dengan mengadakan pengamatan ke lokasi penelitian guna meninjau secara langsung mengenai situasi sebenarnnya. 2) Tes. Tes ini terdiri dari essay, yang terdiri dari 5 soal. Dalam penelitian ini data yang dikumpulkan yaitu hasil dari tes yang dikerjakan oleh siwa yang diajarkan dengan pendekatan Pembelajaran Berbasis Masalah berbantuan Cabri 3D dan hasil belajar siswa yang diajarkan dengan pendekatan open ended berbantuan cabri 3D

\section{Hasil Penelitian dan Pembahasan}

Berdasarkan hasil yang diperoleh dari tes (lampiran 26 dan Lampiran 34), maka diperoleh ratarata, simpangan baku dan varians seperti tabel 4.5 berikut ini.

Tabel 2. Tabel Nilai rata-rata, Simpangan Baku kelas eksperimen I dan kelas Eksperimen II Data

Post-Test

\begin{tabular}{|l|c|c|}
\hline \multicolumn{1}{|c|}{ Parameter } & Kelas Eksperimen I & Kelas Eksperimen II \\
\hline Rata-rata & 74,76 & 67,23 \\
\hline Simpangan Baku & 8,59 & 7,18 \\
\hline Varians & 73,84 & 51,63 \\
\hline
\end{tabular}

Pengujian uji normalitas dilakukan terhadap dua buah data yaitu data nilai pre-test kelas X-A sebagai kelas eksperimen I yaitu Kelas Pembelajaran Berbasis Masalah berbantuan software Cabri 3D dan data nilai pre-test kelas X-B sebagai kelas eksperimen II yaitu kelas Open Ended berbantuan software Cabri 3D dan diperoleh hasil bahwa data berdistribusi normal. Sama halnya dengan penentuan keputusan pada uji normalitas, pada uji homogenitas juga didasarkan pada ketentuan pengujian hipotesis homogenitas yaitu jika nilai Fhitung < Ftabel, pada taraf nyata $=5 \%$ dan $\mathrm{V} 1=\mathrm{n} 1-1=30-1=29$ dan $\mathrm{V} 2=\mathrm{n} 2-1=30-1=29$ maka dinyatakan bahwa kedua data memiliki varians yang homogen, sebaliknya jika Fhitung > Ftabel, maka dinyatakan bahwa kedua data tidak memiliki varians yang homogen. Tampak bahwa hasil perhitungan tersebut nilai Fhitung < Ftabel, sehingga Ha diterima dan HO ditolak, maka diperoleh kesimpulan bahwa kedua data memiliki varians yang homogen.

Setelah melaksanakan pembelajaran dengan menggunakan model pembelajaran Berbasis Masalah berbantuan software cabri 3D dan model pembelajaran Open Ended berbantuan software cabri 3D pada materi Jarak Dalam Ruang maka berdasarkan pada hasil analisis data diperoleh deskripsi data hasil belajar siswa yang diberikan perlakuan dengan menggunakan model pembelajaran pembelajaran Berbasis Masalah berbantuan software cabri 3D dan model pembelajaran Open Ended berbantuan software cabri 3D yang dapat dilihat pada tabel 3 berikut ini:

Tabel 3. Deskripsi Hasil Penelitian

\begin{tabular}{|c|c|c|c|c|}
\hline \multirow{2}{*}{ Parameter } & \multicolumn{2}{|c|}{$\begin{array}{c}\text { Pembelajaran Berbasis Masalah } \\
\text { berbantuan software cabri 3D }\end{array}$} & \multicolumn{2}{|c|}{$\begin{array}{c}\text { Pembelajaran Open Ended } \\
\text { berbantuan software cabri 3D }\end{array}$} \\
\hline & Pre-test & Post-Test & Pre-test & Post-Test \\
\hline $\mathrm{N}$ & 30 & 30 & 30 & 30 \\
\hline $\bar{X}$ & 11,46 & 74,76 & 10,6 & 67,23 \\
\hline$S D$ & 4,79 & 8,59 & 5,24 & 7,18 \\
\hline
\end{tabular}


Berdasarkan tabel di atas bahwa terlihat jelas prestasi hasil belajar siswa yang diajar menggunakan model Pembelajaran Berbasis Masalah berbantuan software cabri 3D lebih baik daripada menggunakan Pembelajaran Open Ended berbantuan software cabri 3D dapat dilihat dari nilai rata-rata siswa yang diberikan perlakuan yang berbeda.

\section{Kesimpulan}

Berdasarkan hasil analisis data dan temuan penelitian, maka peneliti memperoleh kesimpulan bahwa "kemampuan pemecahan masalah matematis siswa yang diajarkan dengan pendekatan pembelajaran berbasis masalah berbantuan software Cabri 3D lebih baik daripada kemampuan pemecahan masalah matematis siswa yang diajarkan dengan pembelajaran Open Ended berbantuan software Cabri 3D pada pokok bahasan Jaraj Dalam Ruang Tiga Dimensi di kelas X SMA Swasta Parulian 1 Medan T.A 2016/2017".

\section{Referensi}

Arends, Richard I., (2008), Learning To Teach (Belajar Untuk Mengajar) Edisi ke Tujuh, Yokyakarta: Pustaka Pelajar.

Depdiknas.2006. Permendiknas No 22 Tahun 2006 Tentang Standar Isi. Jakarta : Depdiknas.

Gultom, Sanggam. 2018. Peningkatankemampuan Pemahaman Matematissiswadengan Menggunakanmodel Pencapaian Konsep. Medan. JPMT: Volume 4(1) https://jpmt.uhn.ac.id/2019/04/05/volume-4-nomor-1-edisi-mei-2018/

Jamil Suprihatiningrum. 2012. Srategi Pembelajaran. Yogyakarta :A-Ruzz Media

Pangaribuan, Lena. 2017. Perbedaan Kemampuan Pemahaman Konsep Matematika Antara Siswa Yang Diberi Pembelajaran Berbasis Masalah Dengan Pembelajaran Langsung. Medan. JPMT: Volume 4(1). https://jpmt.uhn.ac.id/2019/04/05/volume-4-nomor-1-edisimei-2018/

Siahaan, Friska. 2017. Keefektifan Pembelajaran Matematika Dengan Pendekatanmatematika Realistik Terhadap Kemampuan Pemecahanmasalah Matematika Siswa. Medan. JSP: Volume 4(1) https://jsp.uhn.ac.id/2018/03/20/volume-4-edisi-1/

Siagian, Beslina. 2017. Inovasi Pengembangan Metodedouble Loop Problem Solving pada Kemampuan Menulis Teks Anekdot. Medan. JSP: Volume 4(1). https://jsp.uhn.ac.id/2018/03/20/volume-4-edisi-1/

Sianipar, Linda. 2017. Pengaruh Model Pembelajaran Team Quis (Kuis Kelompok)Terhadap Hasil Belajar Pada Mata Pelajaran Ekonomi Kelas XI-IPS SMA Negeri 1 Teluk Mengkudu. Medan. JSP: Volume 4(1). https://jsp.uhn.ac.id/2018/03/20/volume-4-edisi-1/ Sitorus, Parlindungan. 2016. Menumbuhkan Kebiasaan Positif Mahasiswa Untuk Terlibat Aktif Dalam Pembelajaran Mekanika Analitik Melalui Penerapan Strategi Quantum Teaching. Medan. JSP: Volume 3(2). https://jsp.uhn.ac.id/2018/03/16/volume-3-edisi-2/

Situmorang, Adi S. 2018. Desain Model Pembelajaran Creative Problem Solving Terhadap Kemampuan Pemahaman Konsep Mahasiswa FKIP UHN. Medan. Jurnal Penelitian Bidang Pendidikan: V.24(2) https://jurnal.unimed.ac.id/2012/index.php/penelitian/issue/archive

Suherman, E. (2006). Strategi Pembelajaran Matematika Kontemporer. Bandung: JICA-UPI. 